\title{
Perspectives on supply chain quality management research
}

\author{
Nguyen Thi Duc Nguyen, Le Phuc Vinh, Nguyen Thanh Hiep, Huynh Thi Phuong Lan
}

\begin{abstract}
This study focuses on reviewing the current understanding of supply chain quality management research field in order to critically provide a systematic view about the existing relevant literature, and identify shortcomings and further research directions that should be explored. The Creswell's methodology [1] in doing literature review is followed to conduct this study. As a result, three prevailing perspectives in supply chain quality management are (a) Supply chain management \& quality management perspective in which the factors affecting supply chain quality management, integration, coordination, and sharing in supply chain, etc are done. But the sufficient investigation in entire supply chain as well as industry, barriers or facilitators, the role of other functions, quality of the supply chain, upstream-oriented quality activities, and organization learning within partners in the supply chain are less concerned; (b) Supply chain management \& Lean perspective, prior studies identify factors affecting on supply chain performance and firm's competitive advantages, benefits, characteristics, principles, practices and basic techniques for Lean supply chain management, etc. They have less interests in the entire supply chain investigation, Lean service, barriers or facilitators of supply chain quality management performance; and (c) Supply chain management \& Innovation perspective, recent studies investigate factors affecting supply chain innovation, barriers or facilitators, developing innovation frameworks and
\end{abstract}

Bài nhận ngày 02 tháng 08 năm 2017, hoàn chỉnh sưa chũa ngày 07 tháng 11 năm 2017.

This research is funded by Vietnam National University Ho Chi Minh City (VNU-HCM) under grant number C2017-20-42.

Nguyen Thi Duc Nguyen, School of Industrial Management, Ho Chi Minh City University of Technology, VNU-HCM, Vietnam (e-mail: ntdnguyen@hcmut.edu.vn).

Le Phuc Vinh, School of Industrial Management, Ho Chi Minh City University of Technology, VNU-HCM, Vietnam (email: 1414680@hcmut.edu.vn).

Nguyen Thanh Hiep, School of Industrial Management, Ho Chi Minh City University of Technology, VNU-HCM, Vietnam (e-mail: 71301259@hcmut.edu.vn).

Huynh Thi Phuong Lan, School of Industrial Management, Ho Chi Minh City University of Technology, VNU-HCM, Vietnam (e-mail: htplan@hcmut.edu.vn). approaches or strategies, etc. But they reveal limitations in the integration of supply chain strategies with innovation strategies and business strategies, barriers of innovation process, and how to cope with challenges and differences of various types of innovation. Overall, most of the existing researches on three mentioned perspectives mainly investigate within the manufacturing sector in developed countries, and they gives much attention to supply chain fulfillment; few studies focus on supply chain development and lack the combination.

Index Terms-Firm's performance, Lean supply chain management, Quality Management (QM), Supply chain Innovation, Supply chain management (SCM), Supply chain quality management (SCQM).

\section{INTRODUCTION}

$\mathrm{R}$ esearches on supply chain quality management (SCQM) have developed since 2004 [2]. There are many studies that have defined the SCQM in several themes such as (a) Define SCQM using a simple formula, SC means production and distribution network; $\mathrm{Q}$ means meeting demand, achieving customer satisfaction and profitability; $\mathrm{M}$ means allowing conditions and increasing trust among the partners in the supply [3]. It mainly pays attention to customer, vendor relationship and quality of information technology system; (b) SCQM is a coordinated and integrated business activity that engages all partners in the supply chain to measure, analyze, improve products, services, and processes [2]. It values and satisfies the intermediate and end customers of partners within the supply chain; (c) SCQM is the direction, coordination, and implementation of all activities smoothly in the supply chain, which aims to improve operational quality, product quality, and customer satisfaction [4]; and etc. Most of these definitions already recognized the role of SCQM in the activities of the organization, but lack mentions about the importance of SCQM and how to measure, analyze and control the quality of the supply chain. 
Actually, SCQM's operations in practice mainly include such operations as supplier management (supplier assessment, supplier quality management, etc), customer focused activities, internal operations (process management, product design, etc) and complementary activities (human resource management, the support of senior management, and supply chain integration, etc.) [4]. However, organizations have not scientifically approached and applied SCQM to supply chain activities in order to manage firm's performance yet. Moreover, the modern supply chains, especially global supply chains are increasingly complex because they are subject to a variety of both positive and negative factors relating to the global economy, different cultures among regions, policies, environment, etc. At the same time, the fact that the product life cycle is getting shorter forces service level to increase significantly in order to meet the customer's expectation. Therefore, partners in the supply chain are struggling to minimize the cost and maximize service level. On the other hand, the quality elements in the supply chain have been concerned by most managers. Owing to extremely competitive pressures, partners within supply chain have to innovate constantly. Accordingly, innovation needs to be invested in supply chain management to create breakthroughs to ensure the attraction of new customers, increase market share, and get new markets. Therefore, each process in the supply chain must coordinate and integrate together. Generally, the above raising problems are being implemented in practice separately; therefore, the holistic approach to deal with the current supply chain problem is required.

Researches to date on supply chain management mainly pay attentions to various aspects, such as collaboration [5], coordination [6], integration between supply chain partners [7], quality in operation [8], product quality [9], firm's business performance [10], customer satisfaction [4], and etc. Although there are many literature review articles (e.g., $[11,12,13])$; they separately focused on main perspectives in term of SCM and QM, SCM and Lean, and SCM and Innovation, and lack the systematical view among perspectives related to supply chain management.

In conclusion, to address these issues, this study aims to critically provide a systematic view about existing relevant literature, and identify shortcomings and further research directions that should be explored through reviewing the current understanding of SCQM research field.

\section{METHODOLOGY}

This study reviews the current understanding of SCQM researches. Seven steps in the approach of [1] are followed to carry on the literature review: (1) identifying key words such as supply chain management, supply chain innovation, Lean supply chain, QM, and SCQM; (2) using these above keywords to search articles in academic database as Emerald, EBSCO Host, Science Direct, ProQuest, etc., and then found out 123related articles; (3) locating 43 reports of research by setting priority on the research for journal articles and books; (4) looking over the abstracts and skimming the article and chapter to get the sense of current contributions in SCQM literature; (5) arranging relevant literature to position our own study within the larger body of literature; (6) filtering out the 36 most relevant articles that their information is shown in Table I, Fig. 1, Fig. 2, and Fig. 3 and drafting the summaries; and (7) structuring thematically SCQM literature review under three perspectives as SCM \& QM, SCM \& Lean, and SCM \& Innovation which is presented at section 3 .

\section{TABLE 1. THE FOCAL RESEARCHES}

\begin{tabular}{lc}
\hline \hline Journal's Name & $\begin{array}{c}\text { No. of } \\
\text { article }\end{array}$ \\
\hline $\begin{array}{l}\text { Supply Chain Management: An International } \\
\text { Journal }\end{array}$ & 14 \\
International journal of production economics & 3 \\
International Journal of Quality \& Reliability & 3 \\
Management & \\
International Journal of Operations \& Production & 2 \\
Management & 2 \\
Journal of Operations Management & 2 \\
Journal of Supply Chain Management & 1 \\
Advances in Production Management Systems & 1 \\
Business process management journal & 1 \\
Industrial Management \& Data Systems & 1 \\
International Journal for Quality Research & 1 \\
International Journal of Business and Management & 1 \\
Studies & 1 \\
International Journal of Lean Six Sigma & 1 \\
International Journal of Managerial Studies and & 1 \\
Research & 1 \\
Journal of Economic Behavior \& Organization & 1 \\
Journal of Global Strategic Management & 1 \\
Management and Production Engineering Review & 1 \\
\hline \hline
\end{tabular}




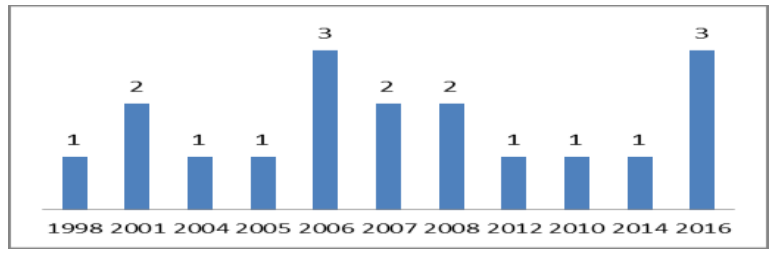

Fig. 1. Year of SCM \& QM

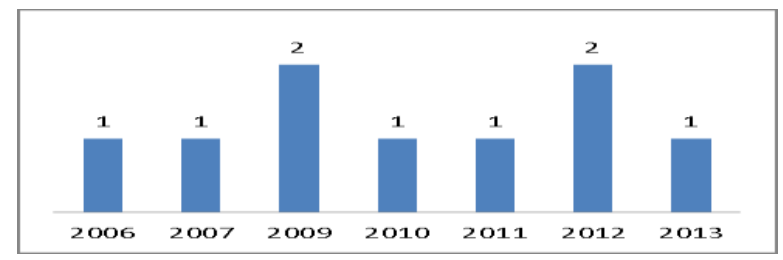

Fig. 2. Year of SCM \& Lean

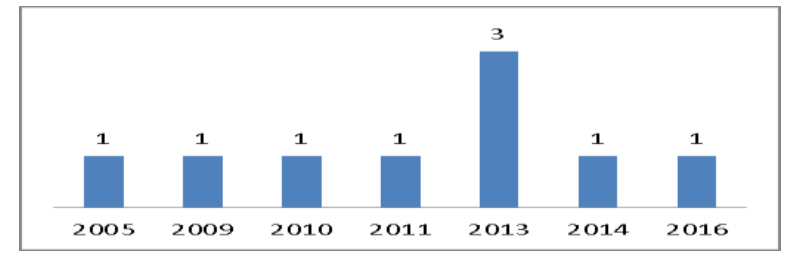

Fig. 3. Year of SCM \& Innovation

\section{RESULTS AND DISCUSSIONS ON SCQM PERSPECTIVES}

The result of literature review about the field of supply chain quality management shows that prior studies approached SCQM under three prominent perspectives (1) QM and SCM, (2) SCM with the implementation of Lean and (3) SCM in the innovation process. The prevailing studies on SCQM are summarized in the Fig. 4 and discussed the following parts in detail.

\subsection{SCM and QM Perspective}

Researches on SCQM under SCM-QM perspective have been investigated in several sectors such as construction, monitors, keyboards and power supply modules, electricity and electronic, machinery, transportation, automation, education, service, agri-food, pharmacy, etc. They focused on mainly various aspects including (a) the facilitators affecting SCQM performance (e.g., $[14,15,16,17])$; (b) inhibitors affecting SCQM performance (e.g., $[14,15,17])$; (c) integration (e.g., [7,18]); (d) coordination (e.g., [19,20,21]); and (e) sharing in supply chain (e.g., [20,22,23]).

Actually, researches in this area were conducted in qualitative and quantitative approach on the basis of quality management. SCQM performance is measured through cost, customer responsiveness, backorders, activity time, and flexibility [24]. Generally, the traditional QM often focuses on internal activities, but it is less widespread in the supply chain [2]. Moreover, current studies on SCQM emphasized the product quality in the supply chain, but insufficiently paid attention to the quality of the supply chain. The fact that researches have much interest in downstream quality activities, such as the focus of product quality management at the distribution channels to increase brand equity, and meet the customer requirements. Therefore, researches in future should be expanded to upstream-oriented quality activities as coordination and integration with suppliers, which would help to improve the quality of the supply chain at first tier, minimize inspection and control, and decrease the waste in the supply chain. Furthermore, the SCQM implementation requires knowledge for continuous improvement, so the future researches should be extended to factors that motivate the collaborative learning in inter- and intra-organizations to enhance customer satisfaction and supply chain performance.

\subsection{SCM and Lean Perspective}

Recent SCQM researches under SCM and Lean perspective have addressed three areas such as benefits of Lean supply chain, characteristics of Lean supply chain, and Lean supply chain management approach (principles, practices, and techniques).

Firstly, the benefits of Lean in the supply chain are considered under following aspects such as responding to customer requests, market penetration, on-time delivery, customer satisfaction, order fulfillment, lead times, flexibility, firm productivity, inventory costs, overall product costs, overall product quality, transportation costs, product cycle time, cost of new product development, etc. (e.g., [12,25,26,27, 28]). Secondly, the characteristics of Lean supply chain are known as information sharing and communication, continuous information and physical flow, coordination and integration of multiple levels among partners in the supply chain, collaborative planning, channel leadership, speed of operations, and inventory level (e.g., [26,29]). Thirdly, Lean supply chain management approach includes principles, practices, and techniques (e.g., [5]). The prominent principles are pull-system, perfection, waste reduction, continuous-flow 
manufacturing, supply chain implementation from the end customer view (e.g., [27]). Relying on the prominent principles, many practices are conducted as analyzing customer demand, producing to meet customer requirements, problem-solving, value chain analysis, system organization, and market research (e.g., [25,28]). In order to implement these practices, the useful techniques are applied as JIT, Kanban system, 5Whys, training, 5S, SMED, small lot production, and VSM (e.g., [9,30]). Above all, partners in supply chains, namely suppliers, manufacturers, distributors, and end customers are involved to implement practices through techniques.

In fact, these reseaches have emphasized the enhancement of quality of supply chain through improving traditional supply chain on the basis of Lean philosophy. However, they are applied on just some components or functions, but lack investigations in whole the supply chain. Currently, several techniques and methods are utilized to conduct these studies, including survey, case study, and simulation-based modeling. Further researches need to be carried on empirical context with advanced techniques to illustrate evidences and predict the benefits of Lean supply chain. Various industries were studied, such as automation, aerospace, telecommunication, food and non-food manufacturing, etc. Future studies should expand in other sectors, e.g., agriculture, service, healthcare, etc. Moreover, the current supply chain streamline has focused on what the Lean supply chain is, and how to achieve the performance of supply chain quality management. However, they still have insufficient interests in other features, e.g., barriers or facilitators for supply chain quality management performance, which should be tackled in future studies.

\subsection{SCM and Innovation Perspective}

Recent SCQM researches which emphasized the improvement of SCM on the basis of innovation perspective relied on three aspects, including barriers, facilitators, and innovative frameworks and approaches. Firstly, these studies identified factors relating to facilitators, such as building trust relationship, information sharing, integration, decision- making, and compatibility of technologies among partners, etc. (e.g., [31,32]). Secondly, barriers affecting the SCQM performance such as insufficient innovation strategies, difficulties in the establishment of trust- based relationships, and the differences between technologies among partners in the supply chain, etc. are paid attentions (e.g., [33,34]). Finally, innovation frameworks and approaches were addressed, including development of new products or processes, specific purposes of building partnerships, project coordinations among members of the supply chain, integration of new product the development process within partners, innovation strategies, etc. (e.g., $[35,36])$.

Consequently, innovation is very important not only for each actor but also for the entire supply chain. However, the impact of innovation on the whole supply chain can only be accomplished effectively through extremely strong collaboration and coordination among actors in the supply chain [37]. Moreover, the SC innovation process is motivated by the factors as trust relationship, shared decision making, the level of integration of information systems, acts of cooperation among the parties, etc. [13]. Thus, in order to enhance effectively SCQM, researches on innovation activities in the whole supply chain should concentrate on focal points of SCM development, which is one of the important aspects that previous studies inappropriately addressed. Besides, when the innovations merged in the traditional supply chain, barriers of innovation process should be identified or predicted. Once innovation implemented, due to several approaches upon types of innovation namely product innovation, process innovation, position innovation, paradigm innovation, etc., there are numerous challenges and differences that need to be solved to increase the effectiveness of each innovation types toward the supply chain performance. Additionally, evaluating and managing the effects of each stage of innovation on SCQM performance are needed. Ultimately, above researches revealed shortcomings in (a) the integration of supply chain strategies, innovation strategies and business strategies, (b) the effects of innovation process on supply chain performance, which should receive more attention in following studies.

In short, after structuring thematically and presenting critically SCQM literature review upon three perspectives in section 3.1, section 3.2 and section 3.3, it finds that most of the researches have recently discovered several aspects, but they are separately investigated and still lacked synthetic approaches in the combination among them. Moreover, in each perspective, current 
studies already focused on a few functions of the supply chain in some sectors; however, they are still less concerned with systematic views in the whole supply chain, which also are extremely important to enhance SCQM performance. Consequently, the shortages of these investigations are mentioned in more detail in Table 2.

TABLE 2. THE MAIN SHORTCOMINGS IN SCQM LITERATURE

\begin{tabular}{|c|c|}
\hline Perspectives & Identified shortcomings \\
\hline SCM \& QM & $\begin{array}{l}\text { - Focus on internal activities of each partner in } \\
\text { the supply chain, but less widespread in the } \\
\text { whole supply chain. } \\
\text { - Emphasize the product quality in the supply } \\
\text { chain, but insufficiently pay attention to the } \\
\text { quality of the supply chain. } \\
\text { - Focus on downstream quality activities, } \\
\text { concentrate less on upstream-oriented quality } \\
\text { activities. } \\
\text { - Lack interests in organization learning } \\
\text { within partners in the supply chain. }\end{array}$ \\
\hline $\begin{array}{c}\text { SCM \& } \\
\text { Lean }\end{array}$ & $\begin{array}{l}\text { - Improve traditional supply chain in several } \\
\text { components and functions on the basis of } \\
\text { Lean philosophy, but limit investigations in } \\
\text { the whole supply chain. } \\
\text { - Use basic techniques and methods to } \\
\text { conduct studies in a few sectors. } \\
\text { - Insufficiently consider barriers or facilitators } \\
\text { of supply chain quality management } \\
\text { performance. }\end{array}$ \\
\hline $\begin{array}{c}\text { SCM \& } \\
\text { Innovation }\end{array}$ & $\begin{array}{l}\text { - Inappropriately concentrate on focal points } \\
\text { of SCM development. } \\
\text { - Lack identifications and predictions toward } \\
\text { barriers of the innovation process in the } \\
\text { supply chain. } \\
\text { - Pay less attentions on how to cope with } \\
\text { challenges and differences of various types of } \\
\text { innovation toward the supply chain } \\
\text { performance. } \\
\text { - Insufficiently integrate supply chain } \\
\text { strategies, innovation strategies with business } \\
\text { strategies, and lack evaluating the effects of } \\
\text { innovation process on supply chain } \\
\text { performance. }\end{array}$ \\
\hline
\end{tabular}

\section{CONCLUSION}

This study provides the insight in SCQM researches in the connection with quality management, Lean and innovation perspective. Most researchers have paid more attention to supply chain fulfillment, but less on supply chain development and lack the combination.
Specifically, this study identifies the shortcomings of three above perspectives: (1) SCM and QM perspective: Lack sufficient investigations in the whole supply chain as well as industry, barriers or facilitators, the role of other functions, quality of the supply chain, upstream-oriented quality activities, and organization learning within partners in the supply chain; (2) SCM and Lean perspective: Limit investigations in the entire supply chain, Lean service, and facilitators and barriers of supply chain quality management performance; (3) SCM and Innovation perspective: Lack the integration of supply chain strategies with innovation strategies and business strategies, the effects of innovation process on supply chain performance, barriers of innovation process, how to cope with challenges and differences of various types of innovation.

As a result, further researches should consider the suggested research directions in Table III, utilize advanced techniques or methods for investigating in various sectors in order to contribute or debate the SCQM current understanding.

TABLE 3. FURTHER RESEARCH DIRECTIONS

\begin{tabular}{|c|c|}
\hline Perspectives & Further research directions \\
\hline $\begin{array}{c}\text { SCM \& } \\
\text { QM }\end{array}$ & $\begin{array}{l}\text { - Identify facilitators/ inhibitors in the whole } \\
\text { supply chain affecting SCQM performance. } \\
\text { - Study upstream-oriented quality activities to } \\
\text { improve the SCQM performance. } \\
\text { - Investigate factors motivating the cooperative } \\
\text { learning in the inter- and intra-organization. }\end{array}$ \\
\hline $\begin{array}{l}\text { SCM \& } \\
\text { Lean }\end{array}$ & $\begin{array}{l}\text { - Indicate facilitators and barriers on the basis } \\
\text { of Lean philosophy upon the whole supply } \\
\text { chain. } \\
\text { - Apply advanced techniques or methods to } \\
\text { investigate SCQM in diversified sectors. } \\
\text { - Identify facilitators and barriers in the SCQM } \\
\text { implement on the basis of Lean philosophy. }\end{array}$ \\
\hline $\begin{array}{c}\text { SCM \& } \\
\text { Innovation }\end{array}$ & $\begin{array}{l}\text { - Develop appropriate approaches } \\
\text { concentrating on focal points of SCM } \\
\text { development. } \\
\text { - Identify barriers to the innovation process in } \\
\text { the supply chain. } \\
\text { - Find out approaches to cope with challenges } \\
\text { and differences of various types of innovation } \\
\text { toward the supply chain performance. } \\
\text { - Investigate the ways to integrate supply chain } \\
\text { strategies, and innovation strategies with } \\
\text { business strategies. } \\
\text { - Evaluate the effects of each stage of } \\
\text { innovation process on SCQM performance. }\end{array}$ \\
\hline
\end{tabular}




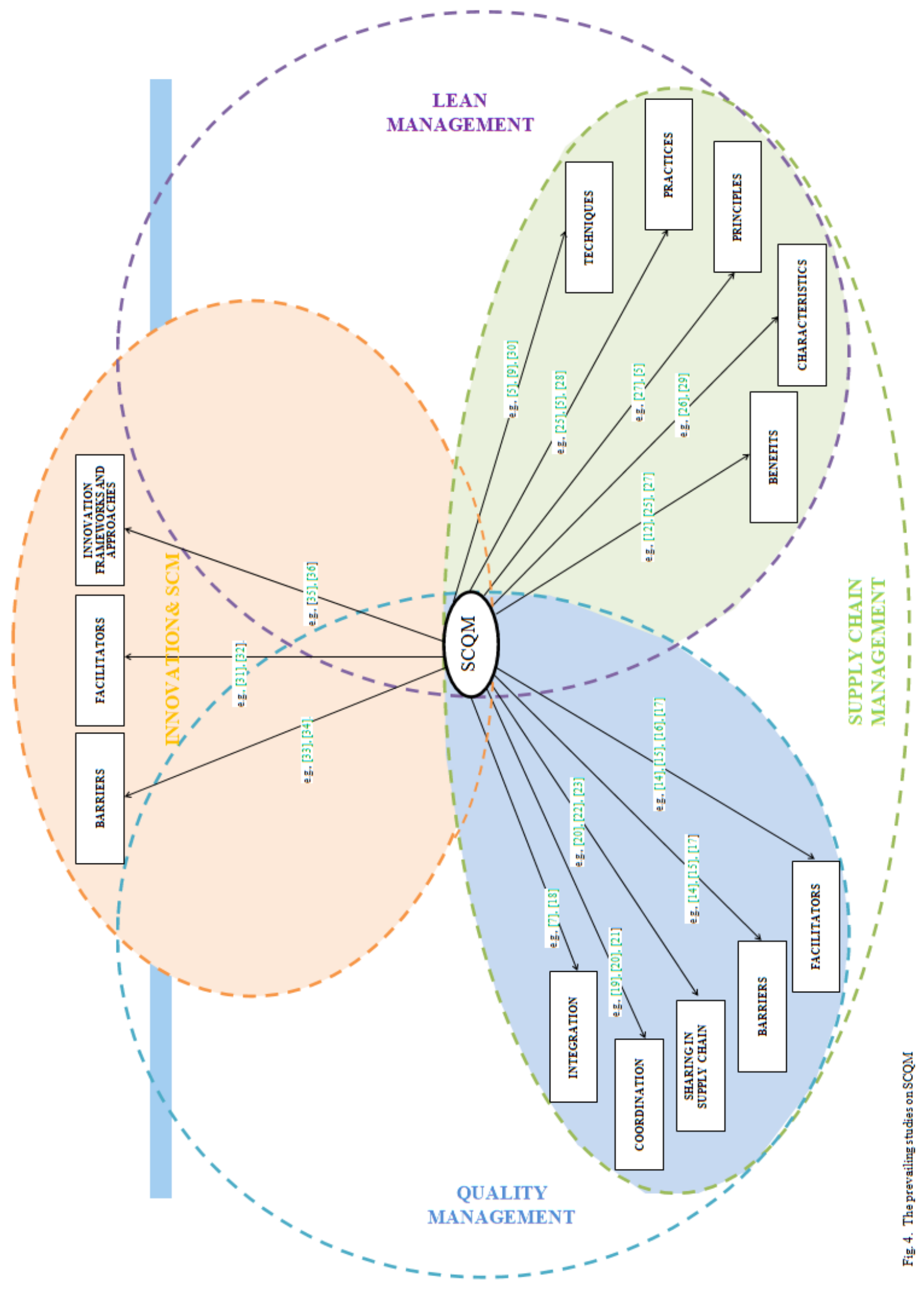




\section{REFERENCES}

[1] J. W. Creswell, "Research design: Qualitative, quantitative, and mixed methods approaches ( $4^{\text {th }} \mathrm{Ed}$.)", UK: Sage Publications, 2014.

[2] C. J. Robinson, and M. K. Malhotra, "Defining the concept of supply chain quality management and its relevance to academic and industrial practice," International Journal of Production Economics, vol. 96, no. 3, pp. 315-337, Jun. 2005. DOI:10.1016/j.ijpe.2004.06.055

[3] C. H. Kuei, C. N. Madu, and C. Lin, "The relationship between supply chain quality management practices and organizational performance," International Journal of Quality \& Reliability Management, vol. 18, no. 8, pp. 864-872, 2001. DOI: 10.1108/EUM0000000006031

[4] H. Truong, P. Sampaio, M. S. Carvalho, A. C. Fernandes, and D. T. B. An, "An extensive structural model of supply chain quality management and firm performance," International Journal of Quality \& Reliability Management, vol. 33, no. 4, pp. 444-464, 2016. DOI: 10.1108/IJQRM-11-2014-0188

[5] P. E. Eriksson, "Improving construction supply chain collaboration and performance: a Lean construction pilot project," Supply Chain Management: An International Journal, vol. 15, no. 5, pp. 394-403, 2010. DOI: 10.1108/13598541011068323

[6] V. M. R. Tummala, C. L. M. Phillips, and M. Johnson, "Assessing supply chain management success factors: a case study," Supply Chain Management: An International Journal, vol. 11 no. 2, pp. 179-192, 2006. DOI $10.1108 / 13598540610652573$

[7] S. W. Kim, "Effects of supply chain management practices, integration and competition capability on performance," Supply Chain Management: An International Journal, vol. 13, no. 1, pp. 241-248, 2006. DOI: $10.1108 / 13598540610662149$

[8] S. A. Dellana, and J. F. Kros, "An exploration of quality management practices, perceptions and program maturity in the supply chain," International Journal of Operations \& Production Management, vol. 34, no. 6, pp. 786-806, 2014. DOI: 10.1108/IJOPM-03-2013-0105

[9] A. Agus, and M. S. Hajinoor, "Lean production supply chain management as driver towards enhancing product quality and business performance: Case study of manufacturing companies in Malaysia," International Journal of Quality \& Reliability Management, vol. 29, no. 1 , pp. 92-121, 2012. DOI: $10.1108 / 02656711211190891$

[10] C. W. Craighead, G. T. M. Hult, and D. J. Ketchen, "The effects of innovation-cost strategy, knowledge, and action in the supply chain on firm performance," Journal of Operations Management, vol. 27, no. 5, pp. 405-421, Oct. 2009. DOI:10.1016/j.jom.2009.01.002

[11] A. Sharma, D. Garg, and A. Agarwal, "Quality management in supply chains: The literature review," International Journal for Quality Research, vol. 6, no. 3, pp. 193-206, 2012.

[12] P. Ugochukwu, J. Engström, and J. Langstrand, "Lean in the supply chain: a literature review," Management and Production Engineering Review, vol. 3, no. 4, pp. 87-96, Dec. 2012. DOI: 10.2478/v10270-012-0037-6
[13] R. Zimmermann, L. M. D. F. Ferreira, and A. C. Moreira, "The influence of supply chain on the innovation process: a systematic literature review," Supply Chain Management: An International Journal, vol. 21, no. 3, pp. 289-304, 2016. DOI: 10.1108/SCM-07-2015-0266

[14] V. H. Lo, and A. Yeung, "Managing quality effectively in supply chain: a preliminary study," Supply Chain Management: An International Journal, vol. 11, no. 3, pp. 208-215, 2006. DOI: 10.1108/13598540610662103

[15] V. R. Kannan, and K. C. Tan, "The impact of operational quality: a supply chain view," Supply Chain Management: An International Journal, vol. 12, no. 1, pp. 14-19, 2007. DOI: 10.1108/13598540710724356

[16] G. Svensson, and H. Bååth, "Supply chain management ethics: conceptual framework and illustration," Supply Chain Management: An International Journal, vol. 13, no. $6, \quad$ pp. 398-405, 2008. DOI $10.1108 / 13598540810905651$

[17] O. T. Okoth, and O. S. Ochieng, "Supply Chain Quality Management Practices and Performance of Pharmaceutical Distributors and Wholesalers in Mombasa, Kenya," International Journal of Managerial Studies and Research, vol. 4, no. 8, pp. 94-102, Aug. 2016. DOI: $10.20431 / 2349-0349.0408008$

[18] B. Huo, Y. Ye, X. Zhao, and K. Zhu, "Supply chain quality integration: A taxonomy perspective," International Journal of Production Economics, vol. 115, no. 5 pp. 923-950, May 2016. DOI: 10.1016/j.ijpe.2016.05.004

[19] F. Salvador, C. Forza, M. Rungtusanatham, and T. Y. Choi, "Supply chain interactions and time-related performances: an operations management perspective," International Journal of Operations \& Production Management, vol. 21 no. 4, pp. 461-475, 2001. DOI: 10.1108/01443570110381372

[20] K. Pramatari, "Collaborative supply chain practices and evolving technological approaches," Supply Chain Management: An International Journal, vol. 12, no. 3, pp. 210-220, 2007. DOI: 10.1108/13598540710742527

[21] D. Papakiriakopoulos, and K. Pramatari, "Collaborative performance measurement in supply chain," Industrial Management \& Data Systems, vol. 110, no. 9, pp. 12971318, 2010. DOI: $10.1108 / 02635571011087400$

[22] C. Morgan, "Structure, speed and salience: performance measurement in the supply chain," Business Process Management Journal, vol. 10, no. 5, pp. 522-536, 2004. DOI: $10.1108 / 14637150410559207$

[23] J. S. C. Lin, and C. R. Chen, "Determinants of manufacturers' selection of distributors," Supply Chain Management: An International Journal, vol. 13, no. 5, pp. 356-365, 2008. DOI: 10.1108/13598540810894942

[24] B. M. Beamon, "Supply chain design and analysis: Models and methods," International Journal of Production Economics, vol. 55, no. 3, pp. 281-294, Aug. 1998. DOI: 10.1016/S0925-5273(98)00079-6

[25] D. H. Taylor, "Strategic considerations in the development of Lean agri-food supply chains: a case study of the UK pork sector," Supply Chain Management: An International Journal, vol. 11, no. 3, pp. 271-280, 2006. DOI 10.1108/13598540610662185

[26] B. Sezen, and S. Erdogan, "Lean philosophy in strategic supply chain management and value creating," Journal of Global Strategic Management, vol. 3, no. 1, pp. 68-73, Jun. 2009. DOI: 10.20460/JGSM.2009318475 
[27] H. M. Wee, and S. Wu, "Lean supply chain and its effect on product cost and quality: a case study on Ford Motor Company," Supply Chain Management: An International Journal, vol. 14, no. 5, pp. 335-341, 2009. DOI: $10.1108 / 13598540910980242$

[28] E. Cudney, and C. Elrod, "A comparative analysis of integrating Lean concepts into supply chain management in manufacturing and service industries," International Journal of Lean Six Sigma, vol. 2, no. 1, pp. 5-22, 2011. DOI: $10.1108 / 20401461111119422$

[29] S. Qrunfleh, and M. Tarafdar, "Lean and agile supply chain strategies and supply chain responsiveness: the role of strategic supplier partnership and postponement," Supply Chain Management: An International Journal, vol. 18 , no. 6 , pp. $571-582$, 2013. DOI: $10.1108 / \mathrm{SCM}-$ 01-2013-0015

[30] M. Eisler, R. Horbal, and T. Koch, "Cooperation of Lean Enterprises-Techniques used for Lean Supply Chain," Advances in Production Management Systems, vol. 246, pp. 363-370, 2007. DOI: 10.1007/978-0-387-74157-4_43

[31] K. J. Preiss, and P. A. Murray, "Fashions of learning: improving supply - chain relationships," Supply Chain Management: An International Journal, vol. 10, no. 1, 18-25, 2005. DOI: $10.1108 / 13598540510578342$

[32] S. B. Modi, and V. A. Mabert, "Exploring the relationship between efficient supply chain management and firm innovation: an archival search and analysis," Journal of Supply Chain Management, vol. 46, no. 4, pp. 81-94, 28 Sep. 2010. DOI: $10.1111 /$ j.1745493X.2010.03207.X

[33] B. Ageron, O. Lavastre, and A. Spalanzani, "Innovative supply chain practices: the state of French companies," Supply Chain Management: An International Journal, vol. 18, no. 3, pp. 265-276, Sep. 2012. DOI: 10.1108/SCM-03-2012-0082

[34] M. Peitz, and D. Shin, "Innovation and waste in supply chain management," Journal of Economic Behavior \& Organization, vol. 86, pp. 191-199, Feb. 2013. DOI: 10.1016/j.jebo.2012.11.013
[35] R. Narasimhan, and S. Narayanan, "Perspectives on supply network-enabled innovations," Journal of Supply Chain Management, vol. 49, no. 4, pp. 27-42, 21 Oct. 2013. DOI: $10.1111 /$ jscm. 12026

[36] S. M. Wagner, and C. Bode, "Supplier relationshipspecific investments and the role of safeguards for supplier innovation sharing," Journal of Operations Management, vol. 32, no.3, pp. 65-78, Mar. 2014. DOI: 10.1016/j.jom.2013.11.001

[37] R. Morvai, and J. Varga, "Innovation in supply chain," International Journal of Business and Management Studies, vol. 3, no. 1, pp. 319-331, 2011.

Nguyễn Thị Đức Nguyên, Lecturer, Department of Production \& Operation Management, School of Industrial Management, Ho Chi Minh City University of Technology, VNU-HCM, Vietnam, E-mail: ntdnguyen@hcmut.edu.vn.

Lê Phúc Vinh, student, School of Industrial Management, Ho Chi Minh City University of Technology, VNU-HCM, Vietnam, E-mail: 1414680@hcmut.edu.vn.

Nguyễn Thanh Hiệp, student, School of Industrial Management, Ho Chi Minh City University of Technology, VNU-HCM, Vietnam, E-mail: 71301259@hcmut.edu.vn.

Huỳnh Thị Phương Lan, Lecturer, Department of Production \& Operation Management, School of Industrial Management, Ho Chi Minh City University of Technology, VNU-HCM, Vietnam, E-mail: htplan@hcmut.edu.vn. 


\section{Khuynh hướng trong nghiên cứu quản lý chất lượng chuỗi cung ứng}

Tóm tắt - Nghiên cứu này tập trung tổng kết những hiểu biết hiện hành trong lĩnh vực nghiên cứu quản lý chất lượng chuỗi cung ứng nhằm cung cấp một cái nhìn có hệ thống về các nghiên cứu có liên quan, xác định các những vấn đề chưa được quan tâm và đề xuất những hướng nghiên cứu tiếp theo. Phương pháp luận về thực hiện tổng quan các nghiên cứu trước của Creswell [1] được vận dụng để thực hiện nghiên cứu này. Kết quả tìm thấy có 3 khuynh hướng nghiên cứu hiện tại trong lĩnh vực nghiên cứu quản lý chất lượng chuỗi cung ứng: (a) Quản lý chuỗi cung ứng và quản lý chất lượng, trong đó những yếu tố ảnh hưởng đến quản lý chất lượng chuỗi cung ứng, tích hợp, hợp tác, và chia sẻ trong chuỗi...đã được đề cập. Tuy nhiên, thiếu sự quan tâm đầy đủ các khía cạnh đã nêu trong toàn bộ chuỗi cũng như trong các ngành công nghiệp, những yếu tố rào cản và thúc đẩy, vai trò của những chức năng khác, chất lượng của chuỗi cung ứng, các hoạt động thực hiện quản lý chất lượng về hướng đầu nguồn trong chuỗi cung ứng và việc học tập tổ chức giữa các thành phần tham gia vào chuỗi. (b) Quản lý chuỗi cung ứng và Lean, trong đó đã chỉ ra các yếu tố ảnh hưởng đến hiệu quả chuỗi cung ứng và lợi thế cạnh tranh của doanh nghiệp, những lợi ích, đặc tính, nguyên lý, cách thực hiện và kỹ thuật để quản lý chuỗi cung ứng tinh gọn... Nhưng thiếu các nghiên cứu trong toàn chuỗi, trong lĩnh vực dịch vụ tinh gọn, chưa quan tâm nhiều vào các yếu tố rào cản và yếu tố thúc đẩy việc thực hiện quản lý chất lượng chuỗi cung ứng. (c) Quản lý chuỗi cung ứng và sự đổi mới, những nghiên cứu hiện tại đã chỉ ra những yếu tố tác động lên việc đổi mới chuỗi cung ứng, những yếu tố rào cản, yếu tố thúc đẩy, và những cách tiếp cận hay chiến lược đồi mới chuỗi. Tuy nhiên, vẫn còn ít quan tâm đến việc tích hợp chiến lược chuỗi cung ứng với chiến lược đổi mới và chiến lược kinh doanh, các yếu tố rào cản trong quá trình đổi mới, cách đối phó với những thách thức và sự khác biệt trong từng giai đoạn của quá trình đổi mới chuỗi cung ứng. Nhìn chung, hầu hết những nghiên cứu hiện tại trong 3 khuynh hướng nghiên cứu đã đề cập chỉ tập trung nghiên cứu vào lĩnh vực sản xuất tại các nước đã phát triển, quan tâm nhiều đến việc thực hiện chuỗi cung ứng, chỉ một vài nghiên cứu tập trung vào việc phát triển chuỗi cung ứng và thiếu sự kết hợp.

Tù $\boldsymbol{k h o ́ a}$ - Kết quả hoạt động kinh doanh của doanh nghiệp; Quản lý chuỗi cung ứng tinh gọn; Quản lý chất lượng; Đổi mới chuỗi cung ứng; Quản lý chuỗi cung ứng; Quản lý chất lượng chuỗi cung ứng 